\title{
Apple Extracts Present Catabolic and Hipocolesterolemic Effect in Mice
}

\author{
Mauricio Poblete1, Amalia Neira², Ricardo Huilcamán1, Iván Palomo1,3, Jose Antonio Yuri²,3, \\ Rodrigo Moore-Carrasco ${ }^{1,3^{*}}$ \\ ${ }^{1}$ Haematology and Immunology Laboratory, Department of Clinical Biochemistry and Immunohaematology, \\ Faculty of Health Sciences, Universidad de Talca, Talca, Chile \\ ${ }^{2}$ Pome Fruit Centre, Faculty of Agricultural Sciences, Universidad de Talca, Talca, Chile \\ ${ }^{3}$ Centre for Studies in Processed Food (CEAP), Regional CONICYT, Gore Maule, Talca, Chile \\ Email: ${ }^{\text {rmoore@utalca.cl }}$
}

Received 29 December 2014; accepted 11 January 2015; published 13 January 2015

Copyright (C) 2015 by authors and Scientific Research Publishing Inc.

This work is licensed under the Creative Commons Attribution International License (CC BY).

http://creativecommons.org/licenses/by/4.0/

c) (i) Open Access

\begin{abstract}
Dyslipidemia is highly prevalent in the Chilean population: about $40 \%$ have total cholesterol levels over $200 \mathrm{mg} / \mathrm{dl}$ and 25\% are obese (BMI > 30) which produces an increased risk of cardiovascular disease and deaths. Over consumption of foods rich in lipids and carbohydrates unchains these events, due to the high amount of lipid accumulation in adipocytes. These cells are capable of producing a large number of mediators of inflammation and adipokines which in large quantities can compromise the overall metabolism. Apple has been shown to stop these events. We used CF-1 mice that were fed on a high-fat diet which leads to a metabolic status similar to dyslipidemia. Different types of apple waste were direct from orchard and fruit industry. Extracts obtained were characterized and administered in drinking water. At the end of the 40-day experimental period, biochemical parameters in animals were measured and the weight of white adipose tissue (WAT) was quantified. The results were compared with the normal diet and fat diet controls. All apple extracts decrease total and LDL cholesterol to levels similar to normal control and decrease WAT. Apple extracts may be an effective protector against development of risk factors in cardiovascular disease in the Chilean population.
\end{abstract}

\section{Keywords}

Cholesterol, Apple, Antioxidants and Metabolic Syndrome

\footnotetext{
${ }^{*}$ Corresponding author.
}

How to cite this paper: Poblete, M., Neira, A., Huilcamán, R., Palomo, I., Yuri, J.A. and Moore-Carrasco, R. (2015) Apple Extracts Present Catabolic and Hipocolesterolemic Effect in Mice. Food and Nutrition Sciences, 6, 141-150.

http://dx.doi.org/10.4236/fns.2015.61015 


\section{Introduction}

Chronic non communicable diseases (NCD), especially cardiovascular diseases (CVD), present a high rate of morbi-mortality in the world: 17.3 million people died in 2008 and it is forecast that about 23.3 million will die by 2030 [1]. According to the National Health Survey conducted in 2010 in Chile [2], the prevalence of high total cholesterol (over $200 \mathrm{mg} / \mathrm{dl}$ ) corresponds to $38.5 \%$ of the population, high levels of LDL cholesterol and triglycerides can also be observed, mainly affecting men and people with low levels of education as shown in Table 1.

The excess of energy intake is mostly responsible for an inappropriate processing of two key components in human energetic metabolism: lipids and glucose. This energy overabundance is stored in adipocytes which released high levels of adipokines and cytokines (IL-6, TNF- $\alpha$, VEGF, etc.) that affect the vascular system [3].

The main problem of increased blood total cholesterol is the development of atherosclerosis. This is the initial step that ends in a cardiovascular disease such as acute myocardial infarction, stroke and coronary artery disease. Cardiovascular disease remains today one of the leading causes of morbidity and mortality in western countries including Chile.

This disease has a multi-factorial pathogenesis: immune, oxidative stress, endotetial injury and increased total cholesterol. There is strong evidence that inflammation localized in arterial intima is key, caused by accumulation of low-density lipoprotein (LDL) in the arterial wall. Furthermore, another triggering event is the oxidation of LDL which activates the endothelial cells, resulting in the recruitment of various immune cells in the subendothelial space, such as peripheral monocytes and T and B lymphocytes. Then, infiltrating monocytes differentiate into dendritic cells that might form foam cells, generating in the interior of the intima a number of cytokines and chemoattractants that develop a cascade of events: recruitment of peripheral immune cells, increased migration and lipoprotein accumulation, and differentiation and proliferation of smooth muscle cells in an environment highly oxidative. This process ends in apoptosis and development of a necrotic core that is known as advanced lesion in the vascular endothelium [4].

At present there is strong scientific evidence that confirms that fruits and vegetables show a beneficial effect on the health of people, specifically for the treatment of obesity and dyslipidemia [5]. The importance of world apple production reached 76,000,000 tons in 2012 [6]. Besides, apple production represents 22\% of phenols consumed in diet [7]. Apple skin, as a by-product of agro industry, and fruits discarded in the orchard, are the raw material that might be used as a source of phenolic antioxidants, to be added to diverse foods.

This availability of apple waste has led to the study of different fruit extracts to establish the probable causes of the beneficial effect. It has been found that extracts of grapes and apples reduce adiposity and improve the plasma lipid profile in different animal models [8]. In this context, apple bioactive compounds have shown a

Table 1. The prevalence of dyslipidemia and obesity that detailed in National Health Survey of Chile 2009-2010 (published with permission).

\begin{tabular}{|c|c|c|c|c|c|c|c|c|}
\hline & \multirow[b]{2}{*}{ Disease } & \multirow[b]{2}{*}{ Standard } & \multirow[b]{2}{*}{$\begin{array}{c}\text { National } \\
\text { total }\end{array}$} & \multicolumn{2}{|c|}{ SEX } & \multicolumn{3}{|c|}{$\begin{array}{l}\text { Educational level } \\
\text { (according to year studying) }\end{array}$} \\
\hline & & & & Men & Women & $<8$ & 8 to 12 & $>12$ \\
\hline \multirow{5}{*}{ Dislipimedia } & Decreased HDL & $\begin{array}{l}<40 \mathrm{mg} / \mathrm{dl} \text { in men, } \\
<50 \mathrm{mg} / \mathrm{dl} \text { women }\end{array}$ & $45.4 \%$ & $37.6 \%$ & $52.8 \%$ & $48.5 \%$ & $48.8 \%$ & $37.2 \%$ \\
\hline & Protected HDL & $\geq 60 \mathrm{mg} / \mathrm{dl}$ & $14.7 \%$ & $8.3 \%$ & $20.8 \%$ & & & \\
\hline & High LDL & $\begin{array}{l}\text { According to ATP III } \\
\text { (fasting up } \geq 9 \text { hour) }\end{array}$ & $22.7 \%$ & $27.2 \%$ & $18.3 \%$ & $35.3 \%$ & $22.8 \%$ & $14.2 \%$ \\
\hline & High triglycerides & $\begin{array}{l}\geq 150 \mathrm{mg} / \mathrm{dl} \\
\text { (fasting up } \geq 9 \text { hour) }\end{array}$ & $31.2 \%$ & $35.6 \%$ & $27.1 \%$ & $34.9 \%$ & $33.0 \%$ & $24.8 \%$ \\
\hline & Total cholesterol high & $>200 \mathrm{mg} / \mathrm{dl}$ & $38.5 \%$ & $39.0 \%$ & $38.1 \%$ & $43.6 \%$ & $39.3 \%$ & $33.8 \%$ \\
\hline \multirow{4}{*}{ Obesity } & Overweight 1 & $\mathrm{BMI} \geq 25$ & $64.5 \%$ & $64.6 \%$ & $64.3 \%$ & $76.4 \%$ & $61.9 \%$ & $61.2 \%$ \\
\hline & Overweight 2 & $\mathrm{BMI} \geq 25, \mathrm{y}<30$ & $39.3 \%$ & $45.3 \%$ & $33.6 \%$ & $40.9 \%$ & $37.2 \%$ & $42.7 \%$ \\
\hline & Obesity & $\mathrm{BMI} \geq 30$ & $25.1 \%$ & $19.2 \%$ & $30.7 \%$ & $35.5 \%$ & $24.7 \%$ & $18.5 \%$ \\
\hline & Extreme obesity & $\mathrm{BMI} \geq 40$ & $2.3 \%$ & $1.3 \%$ & $3.3 \%$ & $5.3 \%$ & $1.5 \%$ & $2.1 \%$ \\
\hline
\end{tabular}


protective effect, especially for their antioxidant [9], hypolipidemic [10] and endothelium protective activity [11]. Different apple extracts have been reported to decrease the weight of visceral adipose tissue as compared to controls. Furthermore it has been found that diets supplemented with apple skin have a positive effect on the lipid profile [12] [13].

However, there is insufficient scientific evidence to determine if the source apple extracts such as traditionally or organically managed orchards, as well as green or red fruits and apple skin from by-product of agroindustry or discarded in the orchard have a better result in the lipid profile [14]-[16]. We studied possible beneficial effects of phenolic antioxidant-rich extracts from skin and small fruits discarded in the orchard in murine model of obesity.

\section{Materials and Methods}

\subsection{Animals}

Male CF1 mice weighing $25 \mathrm{~g}$ were purchased from the Institute of Public Health of Chile. Animals were quarantined for environmental adjustment, at standard conditions $\left(22^{\circ} \mathrm{C} \pm 2^{\circ} \mathrm{C}\right)$ and at a regular light-dark cycle $(12 \mathrm{~h}-12 \mathrm{~h}$ ), with free access to food and water before testing. Thereafter they were divided into groups of 8 mice according to the experimental groups. Animals were kept in group during quarantine and experimental period (40 days) at the Biotery of Universidad de Talca and supervised daily by trained staff.

\subsection{Extract Preparation}

6 apple extract were obtained (organic Fuji (OF) and traditional Fuji (TF); and organic Granny Smith (OGS) and traditional Granny Smith (TGS), as well as apple skin at harvest time (Fuji (FS) and Granny Smith (GSS)) (detail of the extracts found in Table 2) using the following procedure: cutting the waste/peel into small pieces and homogenized with $80 \%$ aqueous EtOH for 6 hours.

In an early stage of patent procedure. The six extracts obtained were administered in the drinking water of the animals as performed by He [17].

\subsection{Determination of Total Phenolics Concentration}

Total phenolics were determined by the Folin-Ciocalteu method. Briefly, $0.1 \mathrm{ml}$ of extract was mixed with 0.5 $\mathrm{ml}$ of the Folin-Ciocalteu phenol reagent (Merck, Darmstadt, Germany). The mixture was incubated for 5 min and then $0.5 \mathrm{ml}$ of sodium carbonate $\left(\mathrm{Na}_{2} \mathrm{CO}_{3} ; 10 \%\right.$, w/v) was added and incubated for $15 \mathrm{~min}$ at room temperature. Absorbance was measured at $640 \mathrm{~nm}$ with the spectrophotometer. Total phenolic concentrations in the peel and diets were expressed as mg of chlorogenic acid equivalents (CAE) $\mathrm{g}^{-1} \mathrm{FW}$.

\subsection{Diet Preparation}

Two types of diet were used, normal (ND) and fat diet (FD). The increased calories of FD were supplemented

Table 2. Characteristics of each group in the study.

\begin{tabular}{|c|c|}
\hline Abbreviation & Characteristic of each group \\
\hline ND & Normal diet free demand \\
\hline FD & Fat diet (FD) \\
\hline FO & FD + apple extract from $c v$ Fuji organic orchard waste $400 \mathrm{mg}$ phenol/kg mice \\
\hline FP & FD + apple extract from $c v$ Fuji Fruit skin (by-product of agro industry) waste $400 \mathrm{mg}$ phenol/kg mice \\
\hline FT & FD + apple extract from $c v$ Fuji traditional orchard waste $400 \mathrm{mg}$ phenol $/ \mathrm{kg}$ mice \\
\hline GSO & FD + apple extract from $c v$ Granny Smith organic orchard waste $400 \mathrm{mg}$ phenol/kg mice \\
\hline GSP & $\begin{array}{c}\text { FD + apple extract from cv Granny Smith Fruit skin (by-product of agro industry) waste } 400 \mathrm{mg} \\
\text { phenol/kg mice }\end{array}$ \\
\hline GST & FD + apple extract from $c v$ Granny Smith traditional orchard waste $400 \mathrm{mg}$ phenol/kg mice \\
\hline
\end{tabular}


with vegetable oil and animal fat. Vitamins and proteins (as peptone) were added to balance the amount of vitamins, minerals and proteins. FD was prepared once a week and kept frozen until use following Moore-Carrasco et al. [18].

Random samples of the diet were taken to the Instituto de Química de los Recursos Naturales de la Universidad de Talca for proximal chemical analysis (percentages of humidity, ashes, lipids or fats, proteins, fibre and elements free of nitrogen) using standardized methods for AOAC [19].

\subsection{Study Groups}

Animals were randomized and divided into groups of 8 animals per experimental group (FO, FP, FT, GSO, GSP, GST), normal diet (ND) control and fat diet (FD) control. Each experimental group received FD plus water with the corresponding extract in drinking water as explained in Table 2. The extract was standardized $400 \mathrm{mg}$ phenols per kilogram of animal weight (400 mg/kg), according to Hogan [20] and toxicology recommendation from Shoji [21] (see antioxidant consumption).

\subsection{Anaesthesia and Sacrifice}

Water and food intake was quantified daily and the mice weight was controlled weekly. The study length was 40 days; at the end of this period animals were anesthetized in fasting condition with an intraperitoneal injection containing a mixture of Ketamine (Richmond, Argentina), Acetopromacine and Xylazine (Centrovet, Chile). Then, blood obtained with $1 \%$ heparin from aorta was centrifuged, separated and frozen at $-70^{\circ} \mathrm{C}$ until analysis to determine plasma: glycemia (GLI), total cholesterol (T-CHOL), cholesterol low density lipoprotein (CHOL LDL) and cholesterol high density lipoprotein (CHOL HDL) by commercial kit ROCHE following manufacturer's instruction in autoanalyzer ROCHE, Elecsys 1010. Organs were also obtained: heart, liver, white adipose tissue (WAT), kidney and gastrocnemius, which were weighed on a precision scale (Shimadzu UX-UW) and frozen at $-70^{\circ} \mathrm{C}$.

Animal handling met all the rules established by the National Commission for Scientific and Technological Research of Chile (CONICYT). All protocols carried out in this work have the approval of the bioethics and bio security committee of Universidad de Talca.

\subsection{Statistical Analysis}

Statgraphics centurion was used for the analysis of the results with an ANOVA statistical test. $\mathrm{p}<0.05$ was considered statistically meaningful.

\section{Results and Discussion}

\subsection{Characterization of Extracts and Diet}

We characterized extract and diet. Table 3 shows the results for each extract obtained, as well as its characterization according to phenol content in each of them. Additionally, characterization of diets to which animals were subjected is shown in Table 3. Difference between both diets was based on lipid contents in ND was 3\% and in FD was $28 \%$. The lipid content of the diets are within the values obtained in accordance previously reported by Moore [18].

\subsection{Results in Animal Model of Dyslipidemia}

Evolution of the weight was expressed in mean \% of weight gain in relation to mean \% initial weight. There is a significant difference between mean \% of weight gained in the FD group (32.8\%) and the rest of the study groups and including ND (Figure 1).

In heart, liver, kidney and gastrocnemius there are no significant difference (Table 4); only visceral white adipose tissue (WAT) showed a significant difference of weight (Figure 2) expressed in mean \% of weight gain of WAT in relation to mean \% initial weight of WAT. Mean weight of WAT in relation to the mean of initial weight shows the difference between the group with FD and ND. Statistical analysis shows that WAT weight decreased considerably in all study groups reaching similar levels to ND group (Figure 2) it means that all groups are statistically different compared to ND group. 


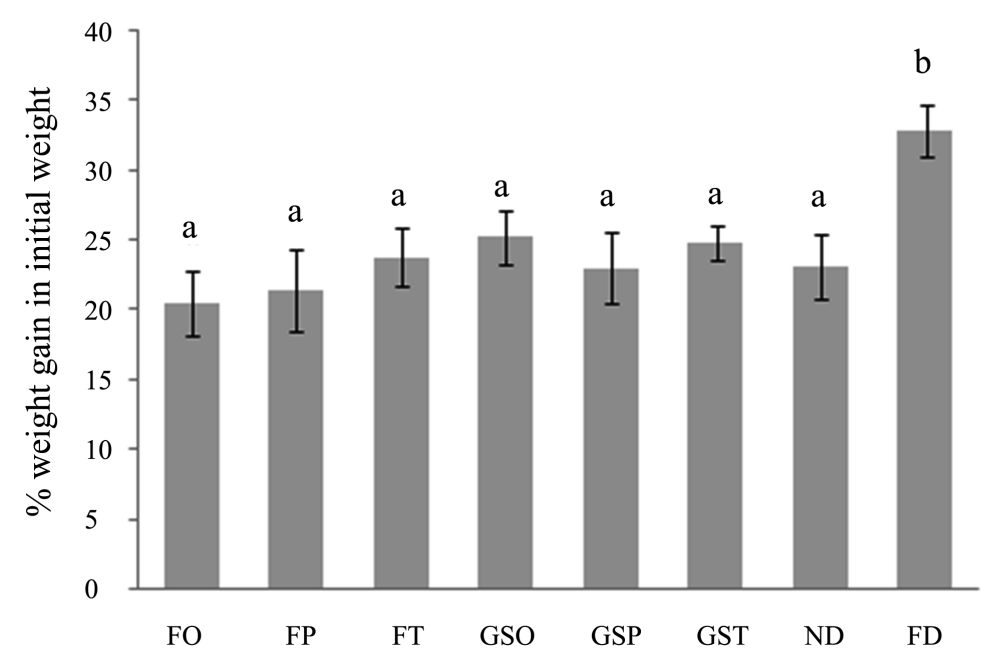

Figure 1. Mean \% of weight gain in relation to mean \% initial weight. Organic Fuji (FO). Fuji skin (FP). Traditional Fuji (TF). Organic Granny Smith (GSO). Granny Smith skin (GSS). Traditional Granny Smith (GST). Normal diet (ND). Fat diet (FD). * Different letters indicate higher significant difference with $p>0.05$. Results are found with mean error (a.e).

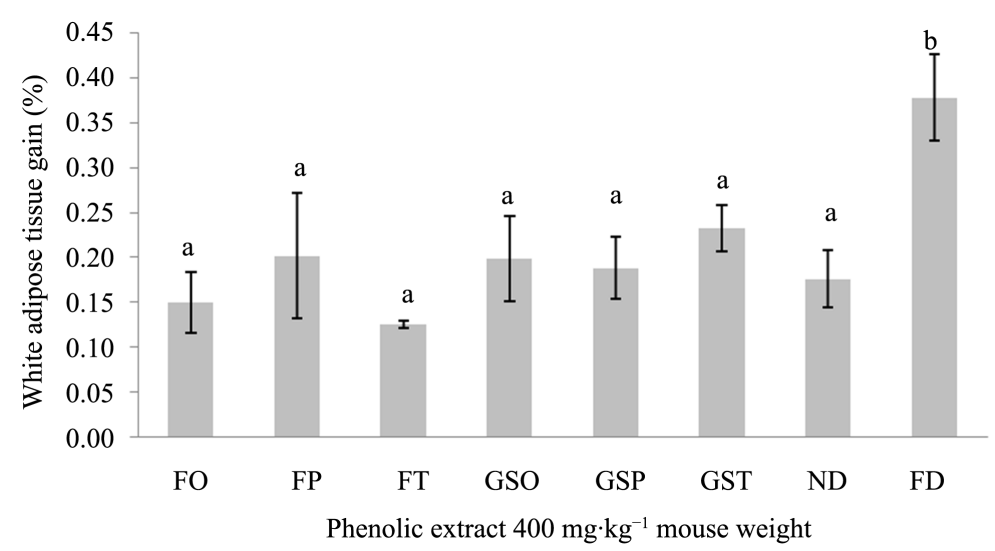

Figure 2. Percentage of WAT gain in $400 \mathrm{mg} \cdot \mathrm{kg}^{-1}$ assay phenolic extract. Weight gain of soft adipose tissue (WAT) according to the percentage of initial weight of the mice. in the trial $400 \mathrm{mg} / \mathrm{kg}$. Organic Fuji (FO). Fuji skin (FP). Traditional Fuji (TF). Organic Granny Smith (GSO). Granny Smith skin (GSS). Traditional Granny Smith (GST). Normal diet (ND). Fat diet (FD). *Different letters indicate higher significant difference with $\mathrm{p}>0.05$. Results are found with mean error (a.e).

There have been studies showing that apple extracts are one of the few fruits that have demonstrated antiobesity effect. Boque et al. conducted a screening of different plants (almond, apple, cinnamon, orange, witch hazel, lime blossom, grape, birch) activities anti-obesity seeking in Wistar rats [22], finding that only extracts of apple and cinnamon were considered anti-obesity because of their effects in reducing body fat (body fat-lowering) in the animals.

Studies have confirmed this trend in animal models, Cho [12] testing pome apple (PA) and apple juice concentrate (AJC) on different groups with a high fat diet. They found that the groups which were supplied with PA and AJC in the presence of high-fat diet had a lower weight, lower total CHOL, lower CHOL LDL, while CHOL HDL was significantly higher in the PA group compared with AJC. The results suggest that products supplemented with PA and AJC can help suppress the increase in WAT and improve the lipid profile in obese rats, supporting our results. 
Table 3. Proximal chemistry and phenol quantification for each obtained extracts and diets administered.

\begin{tabular}{lccccccccc}
\hline & \% water & \% proteins & \% lipids & \% ashes & \% fiber & \% NFE & $\begin{array}{c}\text { Total mass } \\
\text { extract (gr) }\end{array}$ & $\begin{array}{c}\text { Total phenols present in } \\
\text { the extract (gr) }\end{array}$ & $\begin{array}{c}\text { \% total } \\
\text { phenols }\end{array}$ \\
\hline FO & 1.8 & 0.6 & 3.8 & 4.6 & 0.5 & 88.7 & 22.1 & 6.7 & 30 \\
FP & 1.8 & 2.6 & 12.3 & 11.4 & 1.1 & 70.8 & 104.7 & 4.3 & 5 \\
FT & 2.5 & 1.2 & 2.5 & 3.7 & 0.3 & 89.8 & 23.6 & 7.5 & 32 \\
GSO & 1.9 & 0.4 & 1.2 & 1.8 & 0.2 & 94.5 & 19.4 & 7.4 & 38 \\
GSP & 2.1 & 1.1 & 2.5 & 6.7 & 1.3 & 86.4 & 28.1 & 5.9 & 21 \\
GST & 2.3 & 0.8 & 2.9 & 5.7 & 1.3 & 87.0 & 42.1 & 7.4 & -18 \\
ND & 10 & 20 & 3 & 3 & 1 & 63 & - & - & - \\
FD & 7 & 17 & 28 & 6 & 2 & 40 & - & & - \\
\hline
\end{tabular}

NFE: nitrogen free elements. FO: organic Fuji. FP: Fuji skin. FT: traditional Fuji. GSO: organic Granny Smith. GSS: Granny Smith skin. GST: traditional Granny Smith. ND: normal diet. FD: fat diet.

\section{Table 4. Weight from different organs.}

\begin{tabular}{|c|c|c|c|c|}
\hline & Heart & Liver & Kidney & Gastrocnemius \\
\hline FO & $0.17 \pm 0.02 \mathrm{a}$ & $5.25 \pm 0.04 \mathrm{ab}$ & $1.83 \pm 0.02 \mathrm{ab}$ & $0.57 \pm 0.03 \mathrm{a}$ \\
\hline FP & $0.22 \pm 0.02$ bc & $5.81 \pm 0.09 \mathrm{c}$ & $1.78 \pm 0.01 \mathrm{a}$ & $0.64 \pm 0.07 \mathrm{abc}$ \\
\hline FT & $0.22 \pm 0.01$ bc & $5.22 \pm 0.05 a b$ & $1.86 \pm 0.01 \mathrm{abc}$ & 0.630 .01 bc \\
\hline GSO & $0.22 \pm 0.01 \mathrm{bc}$ & $5.29 \pm 0.07 \mathrm{a}$ & $1.95 \pm 0.01 \mathrm{ab}$ & $0.67 \pm 0.01$ bc \\
\hline GSP & $0.19 \pm 0.02 a b$ & $5.52 \pm 0.04$ bc & $1.90 \pm 0.01 \mathrm{abc}$ & $0.72 \pm 0.03 \mathrm{c}$ \\
\hline GST & $0.22 \pm 0.01 \mathrm{abc}$ & $6.33 \pm 0.07 \mathrm{~d}$ & $1.66 \pm 0.01 \mathrm{a}$ & $0.64 \pm 0.05 a b c$ \\
\hline ND & $0.65 \pm 0.05$ bc & $5.80 \pm 0.33 \mathrm{~cd}$ & $1.97 \pm 0.08 \mathrm{c}$ & $0.67 \pm 0.06 \mathrm{bc}$ \\
\hline FD & $0.67 \pm 0.04 \mathrm{c}$ & $5.79 \pm 0.13 d$ & $1.81 \pm 0.03 \mathrm{bc}$ & $0.64 \pm 0.03 b c$ \\
\hline
\end{tabular}

NFE: nitrogen free elements. FO: organic Fuji. FP: Fuji skin. FT: traditional Fuji. GSO: organic Granny Smith. GSS: Granny Smith skin. GST: traditional Granny Smith. ND: normal diet. FD: fat diet.

\subsection{Phenolics of Apple Peel/Discard Consumption and Feeding}

The administration of phenols of apple peel/discard to animals was $400 \mathrm{mg} / \mathrm{kg}$ mouse weight according to their initial weight. The amount of food that was consumed during the assay per group was between $1.311 \mathrm{gr}$ (FP and GSP) and 1.451 gr (FO).

\subsection{Biochemical Parameters}

Table 5 shows biochemical results obtained in plasma of test mice dosed $400 \mathrm{mg}$ of phenol $/ \mathrm{kg}$. In mice subjected to FD and the contribution of different apple extracts, a decrease of CHOL TOT, CHOL LDL and an increase of CHOL HDL was observed with all extracts studied, at similar level to the ND group. Levels of CHOL LDL and CHOL HDL are in Table 5. No difference was found between the extract from discarded fruit or apple skin. Our obtained results allow inferring that the extract consumed by animals in the study (400 mg phenols/kg) decreases the content of total cholesterol and LDL cholesterol, and increases HDL cholesterol, with WAT decrease playing a key role. Results confirm the findings of other researchers, in which cholesterol accumulation in rabbits in the ascending aorta decreased with the administration of quercetin glucoside [23]. Also, in obese Zucker rats that consumed apples, cholesterol level decreased [24]. Another study which confirms apple use for plasma cholesterol decrease in model animals was carried out by Leontowicz et al. [13] in which skin and pulp 
Table 5. Summary of biochemical mean results for experiment $400 \mathrm{mg} \cdot \mathrm{kg}^{-1}$.

\begin{tabular}{cccc}
\hline & ${\text { CHOL HDL }(\mathbf{m g} / \mathbf{d l})^{*}}^{*}$ & ${\text { CHOL LDL }(\mathbf{m g} / \mathbf{d l})^{*}}^{*}$ & CHOL TOT (mg/dl) $^{*}$ \\
\hline FO & $92 \pm 8.4 \mathrm{~b}$ & $95 \pm 12.7 \mathrm{~d}$ & $152 \pm 9.4 \mathrm{c}$ \\
FP & $98 \pm 5 \mathrm{~b}$ & $40 \pm 11.4 \mathrm{~d}$ & $90 \pm 26.1 \mathrm{a}$ \\
FT & $90 \pm 10.1 \mathrm{~b}$ & $62 \pm 19.9 \mathrm{bc}$ & $111 \pm 36.4 \mathrm{ab}$ \\
GSO & $96 \pm 9.4 \mathrm{~b}$ & $53 \pm 5.6 \mathrm{ab}$ & $131 \pm 36.6 \mathrm{bc}$ \\
GSP & $97 \pm 5.6 \mathrm{~b}$ & $53 \pm 18.4 \mathrm{ab}$ & $115 \pm 19.6 \mathrm{ab}$ \\
GST & $86 \pm 7.5 \mathrm{~b}$ & $77 \pm 15 \mathrm{~cd}$ & $114 \pm 18.7 \mathrm{ab}$ \\
ND & $80 \pm 8.8 \mathrm{~b}$ & $33 \pm 3.1 \mathrm{a}$ & $119 \pm 23.1 \mathrm{abc}$ \\
FD & $13 \pm 6.2 \mathrm{a}$ & $217 \pm 33 \mathrm{e}$ & $252 \pm 37.2 \mathrm{~d}$ \\
\hline
\end{tabular}

CHOL TOT: total cholesterol. CHOL HDL: HDL cholesterol. CHOL LDL: LDL cholesterol. NFE: nitrogen free elements. FO: organic Fuji. FP: Fuji skin. FT: traditional Fuji. GSO: organic Granny Smith. GSS: Granny Smith skin. GST: traditional Granny Smith. ND: normal diet. FD: fat diet. ${ }^{*}$ Different letters indicate higher significant difference with $\mathrm{p}>0.05$. Results are found with the mean error.

was used at the ripeness peak. In this report we used fruits discarded in orchard and skin waste from fruit processing. Components that are present in apple presenting the beneficial effect in reducing CHOL are complex polysaccharides such as pectin and different polyphenol. Aprikian [24] separated these compounds and demonstrated that they produce a greater decrease in the lipid profile in Wistar rats acting together than separately. A high correlation has been found between anti-hypercholesterolemic effects and certain compounds present in apple like catechin, epicatechin, procyanidin B1 and $\beta$-carotene which would be primarily responsible phytocompounds by lowering cholesterol by this fruit [25]. It is necessary to explain the mechanisms by which metabolites present in apples as well as in its extracts produce a decrease in plasmatic cholesterol levels in mammals. In this respect, two hypotheses have been proposed: 1) The component or components present in apples as well as in its extracts can inhibit cholesterol absorption, as pointed out by Koo et al. [26], who details decrease in plasma cholesterol for the effect of catechin present in green tea. This effect would be due to the inhibition of lipid absorption in the intestine and the inhibition of lipid hydrolysis, mostly pancreatic lipase and pancreatic phospholipase A2. These findings have been reaffirmed by meta-analysis reviews [27]. In future trials, lipid concentrations in the faeces of animals during the experiment might be quantified, and studies might focus on transporters and enzymes in the intestines, either in animal models or cellular cultures that are related to cholesterol absorption.

2) According to another hypothesis, there is evidence that compounds present in apples and their extracts interfere in cholesterol metabolism; this was demonstrated by Osada et al. [28]. It has been proposed that Ursolic acid, present in fruit, is capable of modulating cholesterol catabolism, producing increase of muscle mass and brown adipose tissue (BAT), decreasing obesity, glucose intolerance and fatty liver [29]. This work would explain, in turn, WAT decrease in studied mice [30]. This effect has also been confirmed in another animal model such as the Wistar rats, showing improved glucose tolerance to a diet high in fructose and improved lipolytic response of adipocytes, proposing that the anti-obesity effects are achieved through the regulation of genes included in adipogenesis, lipolysis and oxidation of fatty acids, reducing the expression of mRNA of SREBF1 and increasing aquaporin 7 (AQP7), adipocyte binding enhancer protein 1 (Aebp1) and peroxisome proliferator activator receptor gamma co-1 alpha (PPARGC1A) [31].

Important efforts have been made in the search of functional ingredients from apple pulp and skin, in order to incorporate them in healthier food for the population [32]. In this study, supplies to prepare the fruit extracts obtained from fruit discarded in orchard and the apple skin waste from fruit processing, both considered discards of low commercial value.

The contribution of mediterranean diet to the health of people consuming it has been widely studied and associated to a decrease of cardiovascular diseases [33]-[35]. Of foods that are consumed, one of the main candidate compounds are the phenols which have high antioxidant capacity [36].

\section{Conclusion}

Obtaining an extract with a high content of antioxidants, in this case of apples, should improve parameters 
which are altered in plasmatic cholesterol. This work shows that important metabolites can be obtained from unused items in apple production, such as discard from orchard fruit and apple skin waste, and that these metabolites can decrease plasma cholesterol levels and the WAT weight in studied mice. In addition, there are no differences between red or green variety or if they come from a traditional or organic agronomic management: all experimental groups present decreased total cholesterol and increased HDL cholesterol which suggest the potential beneficial effects of regular consumption of these products favouring protection to cardiovascular disease. These findings need further studies to explain the mechanisms of action.

\section{Acknowledgements}

FONDEF Project AF 10I1022. Master Scholarship Programme CONICYT-FIC Maule Regional Government.

\section{Disclosure Policy}

The author(s) declare(s) that there is no conflict of interests regarding the publication of this paper.

\section{References}

[1] Mendis, S., Puska, P. and Norrving, B. (2011) Global Atlas on Cardiovascular Disease Prevention and Control. WHO Library Cataloguing-in-Publication Data, Geneva.

[2] Ministerio de Salud (2010) Encuesta de Salud.

[3] Galic, S., Oakhill, J.S. and Steinberg, G.R. (2010) Adipose Tissue as an Endocrine Organ. Molecular and Cellular Endocrinology, 316, 129-139. http://dx.doi.org/10.1016/j.mce.2009.08.018

[4] Ponnuswamy, P., Van Vré, E.A., Mallat, Z. and Tedgui, A. (2012) Humoral and Cellular Immune Responses in Atherosclerosis: Spotlight on B- and T-Cells. Vascular Pharmacology, 56, 193-203. http://dx.doi.org/10.1016/j.vph.2012.01.009

[5] Palomo, G.I., Fuentes, Q.E., Moore-Carrasco, R., González, D.R., Rojas, R.A., Padro, T., et al. (2011) El consumo de frutas y hortalizas ayuda a prevenir el daño endotelial. Revista Chilena de Nutrición, 38, 343-355. http://dx.doi.org/10.4067/S0717-75182011000300010

[6] Agencia Regional de Desarrollo Productivo Maule (2010) Informe de Productividad año 2010.

[7] Zessner, H., Pan, L., Will, F., Klimo, K., Knauft, J., Niewöhner, R., et al. (2008) Fractionation of Polyphenol-Enriched Apple Juice Extracts to Identify Constituents with Cancer Chemopreventive Potential. Molecular Nutrition Food Research, 52, S28-S44.

[8] Caimari, A., del Bas, J.M., Crescenti, A. and Arola, L. (2013) Low Doses of Grape Seed Procyanidins Reduce Adiposity and Improve the Plasma Lipid Profile in Hamsters. International Journal of Obesity, 37, 576-583. http://dx.doi.org/10.1038/ijo.2012.75

[9] Yuri, J.A., Neira, A., Quilodran, A., Motomura, Y. and Palomo, I. (2009) Antioxidant Activity and Total Phenolics Concentration in Apple Peel and Flesh Is Determined by Cultivar and Agroclimatic Growing Regions in Chile. Journal of Food, Agriculture \& Environment, 7, 513-517.

[10] Leontowicz, H., Gorinstein, S., Lojek, A., Leontowicz, M., Ciz, M., Soliva-Fortuny, R., et al. (2002) Comparative Content of Some Bioactive Compounds in Apples, Peaches and Pears and Their Influence on Lipids and Antioxidant Capacity in Rats. Journal of Nutritional Biochemistry, 13, 603-610. http://dx.doi.org/10.1016/S0955-2863(02)00206-1

[11] Perez-Vizcaino, F. and Duarte, J. (2010) Flavonols and Cardiovascular Disease. Molecular Aspects of Medicine, 31, 478-494. http://dx.doi.org/10.1016/j.mam.2010.09.002

[12] Cho, K.D., Han, C.K. and Lee, B.H. (2013) Loss of Body Weight and Fat and Improved Lipid Profiles in Obese Rats Fed Apple Pomace or Apple Juice Concentrate. Journal of Medicinal Food, 16, 823-830. http://dx.doi.org/10.1089/jmf.2013.2784

[13] Leontowicz, M., Gorinstein, S., Leontowicz, H., Krzeminski, R., Lojek, A., Katrich, E., et al. (2003) Apple and Pear Peel and Pulp and Their Influence on Plasma Lipids and Antioxidant Potentials in Rats Fed Cholesterol-Containing Diets. Journal of Agricultural and Food Chemistry, 51, 5780-5785. http://dx.doi.org/10.1021/jf030137j

[14] Brandt, K. and Mølgaard, J.P. (2001) Organic Agriculture: Does It Enhance or Reduce the Nutritional Value of Plant Foods? Journal of the Science of Food and Agriculture, 81, 924-931. http://dx.doi.org/10.1002/jsfa.903

[15] Valavanidis, A., Vlachogianni, T., Psomas, A., Zovoili, A. and Siatis, V. (2009) Polyphenolic Profile and Antioxidant Activity of Five Apple Cultivars Grown under Organic and Conventional Agricultural Practices. International Journal of Food Science \& Technology, 44, 1167-1175. http://dx.doi.org/10.1111/j.1365-2621.2009.01937.x 
[16] Yuri, J., Maldonado, F., Razmilic, I., Neira, A., Quilodrán, A. and Palomo, I. (2012) Concentrations of Total Phenols and Antioxidant Activity in Apple Do Not Differ between Conventional and Organic Orchard Management. Journal of Food Agriculture \& Environment, 10, 207-216.

[17] He, R.R., Wang, M., Wang, C.Z., Chen, B.T., Lu, C.N., Yao, X.S., et al. (2011) Protective Effect of Apple Polyphenols against Stress-Provoked Influenza Viral Infection in Restraint Mice. Journal of Agricultural and Food Chemistry, 59, 3730-3737. http://dx.doi.org/10.1021/jf104982y

[18] Moore-Carrasco, R., Aranguez-Arellano, C., Razmilic, I., Toloza, L., Morales, E., Argiles, J.M. and Palomo, I. (2008) A High Fat Diet in CF-1 Mice: An Experimental Model for Metabolic Syndrome. Molecular Medicine Reports, 1, 401405.

[19] Helrich, K. (1990) Official Method of Analysis of the AOAC. 15th Edition, Association of Official Analytical Chemists, Rockville.

[20] Hogan, S., Zhang, L., Li, J., Sun, S., Canning, C. and Zhou, K. (2010) Antioxidant Rich Grape Pomace Extract Suppresses Postprandial Hyperglycemia in Diabetic Mice by Specifically Inhibiting Alpha-Glucosidase. Nutrition \& Metabolism, 7, 71. http://dx.doi.org/10.1186/1743-7075-7-71

[21] Shoji, T., Akazome, Y., Kanda, T. and Ikeda, M. (2004) The Toxicology and Safety of Apple Polyphenol Extract. Food and Chemical Toxicology, 42, 959-967. http://dx.doi.org/10.1016/j.fct.2004.02.008

[22] Boqué, N., Campión, J., de la Iglesia, R., de la Garza, A.L., Milagro, F.I., San Román, B., et al. (2013) Screening of Polyphenolic Plant Extracts for Anti-Obesity Properties in Wistar Rats. Journal of the Science of Food and Agriculture, 93, 1226-1232. http://dx.doi.org/10.1002/jsfa.5884

[23] Kamada, C., da Silva, E.L., Ohnishi-Kameyama, M., Moon, J.H. and Terao, J. (2005) Attenuation of Lipid Peroxidation and Hyperlipidemia by Quercetin Glucoside in the Aorta of High Cholesterol-Fed Rabbit. Free Radical Research, 39, 185-194. http://dx.doi.org/10.1080/10715760400019638

[24] Aprikian, O., Busserolles, J., Manach, C., Mazur, A., Morand, C., Davicco, M.J., et al. (2002) Lyophilized Apple Counteracts the Development of Hypercholesterolemia, Oxidative Stress, and Renal Dysfunction in Obese Zucker Rats. Journal of Nutrition, 132, 1969-1976.

[25] Serra, A.T., Rocha, J., Sepodes, B., Matias, A.A., Feliciano, R.P., de Carvalho, A., et al. (2012) Evaluation of Cardiovascular Protective Effect of Different Apple Varieties-Correlation of Response with Composition. Food Chemistry, 135, 2378-2386. http://dx.doi.org/10.1016/j.foodchem.2012.07.067

[26] Koo, S.I. and Noh, S.K. (2007) Green Tea as Inhibitor of the Intestinal Absorption of Lipids: Potential Mechanism for Its Lipid-Lowering Effect. Journal of Nutritional Biochemistry, 18, 179-183. http://dx.doi.org/10.1016/j.jnutbio.2006.12.005

[27] Kim, A., Chiu, A., Barone, M.K., Avino, D., Wang, F., Coleman, C.I. and Phung, O.J. (2011) Green Tea Catechins Decrease Total and Low-Density Lipoprotein Cholesterol: A Systematic Review and Meta-Analysis. Journal of the American Dietetic Association, 111, 1720-1729. http://dx.doi.org/10.1016/j.jada.2011.08.009

[28] Osada, K., Suzuki, T., Kawakami, Y., Senda, M., Kasai, A., Sami, M., et al. (2006) Dose-Dependent Hypocholesterolemic Actions of Dietary Apple Polyphenol in Rats Fed Cholesterol. Lipids, 41, 133-139. http://dx.doi.org/10.1007/s11745-006-5081-y

[29] Kunkel, S.D., Elmore, C.J., Bongers, K.S., Ebert, S.M., Fox, D.K., Dyle, M.C., et al. (2012) Ursolic Acid Increases Skeletal Muscle and Brown Fat and Decreases Diet-Induced Obesity, Glucose Intolerance and Fatty Liver Disease. PLoS ONE, 7, e39332. http://dx.doi.org/10.1371/journal.pone.0039332

[30] Rao, V.S., de Melo, C.L., Queiroz, M.G.R., Lemos, T.L.G., Menezes, D.B., Melo, T.S. and Santos, F.A. (2011) Ursolic Acid, a Pentacyclic Triterpene from Sambucus australis, Prevents Abdominal Adiposity in Mice Fed a High-Fat Diet. Journal of Medicinal Food, 14, 1375-1382. http://dx.doi.org/10.1089/jmf.2010.0267

[31] Boqué, N., de la Iglesia, R., de la Garza, A.L., Milagro, F., Olivares, M., Bañuelos, Ó., et al. (2013) Prevention of DietInduced Obesity by Apple Polyphenols in Wistar Rats through Regulation of Adipocyte Gene Expression and DNA Methylation Patterns. Molecular Nutrition \& Food Research, 57, 1473-1478. http://dx.doi.org/10.1002/mnfr.201200686

[32] Shahidi, F. (2009) Nutraceuticals and Functional Foods: Whole versus Processed Foods. Trends in Food Science \& Technology, 20, 376-387. http://dx.doi.org/10.1016/j.tifs.2008.08.004

[33] Sofi, F., Cesari, F., Abbate, R., Gensini, G.F. and Casini, A. (2008) Adherence to Mediterranean Diet and Health Status: Meta-Analysis. British Medical Journal, 337, a1344. http://dx.doi.org/10.1136/bmj.a1344

[34] Urpi-Sarda, M., Casas, R., Chiva-Blanch, G., Romero-Mamani, E.S., Valderas-Martínez, P., Arranz, S., et al. (2012) Virgin Olive Oil and Nuts as Key Foods of the Mediterranean Diet Effects on Inflammatory Biomarkers Related to Atherosclerosis. Pharmacological Research, 65, 577-583. http://dx.doi.org/10.1016/j.phrs.2012.03.006

[35] Bonaccio, M., Iacoviello, L. and de Gaetano, G., on Behalf of the Moli-Sani Investigators (2012) The Mediterranean 
Diet: The Reasons for a Success. Thrombosis Research, 129, 401-404.

[36] Nadtochiy, S.M. and Redman, E.K. (2011) Mediterranean Diet and Cardioprotection: The Role of Nitrite, Polyunsaturated Fatty Acids, and Polyphenols. Nutrition, 27, 733-744. http://dx.doi.org/10.1016/j.nut.2010.12.006 
Scientific Research Publishing (SCIRP) is one of the largest Open Access journal publishers. It is currently publishing more than 200 open access, online, peer-reviewed journals covering a wide range of academic disciplines. SCIRP serves the worldwide academic communities and contributes to the progress and application of science with its publication.

Other selected journals from SCIRP are listed as below. Submit your manuscript to us via either submit@scirp.org or Online Submission Portal.
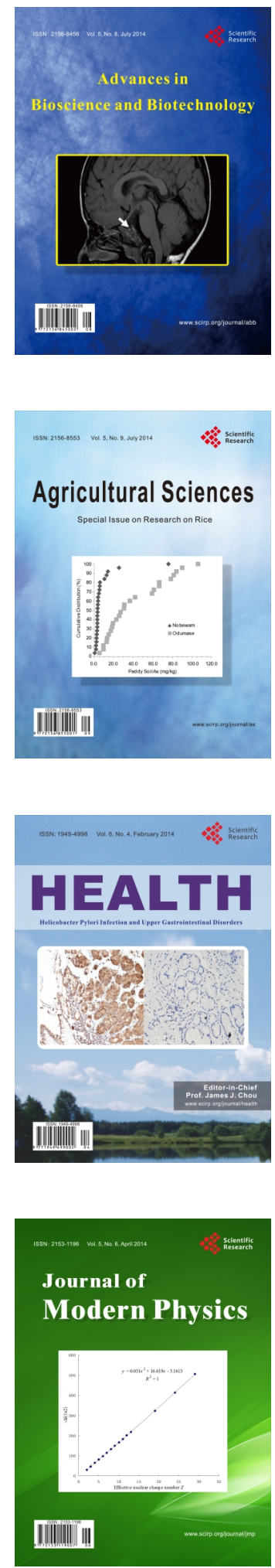
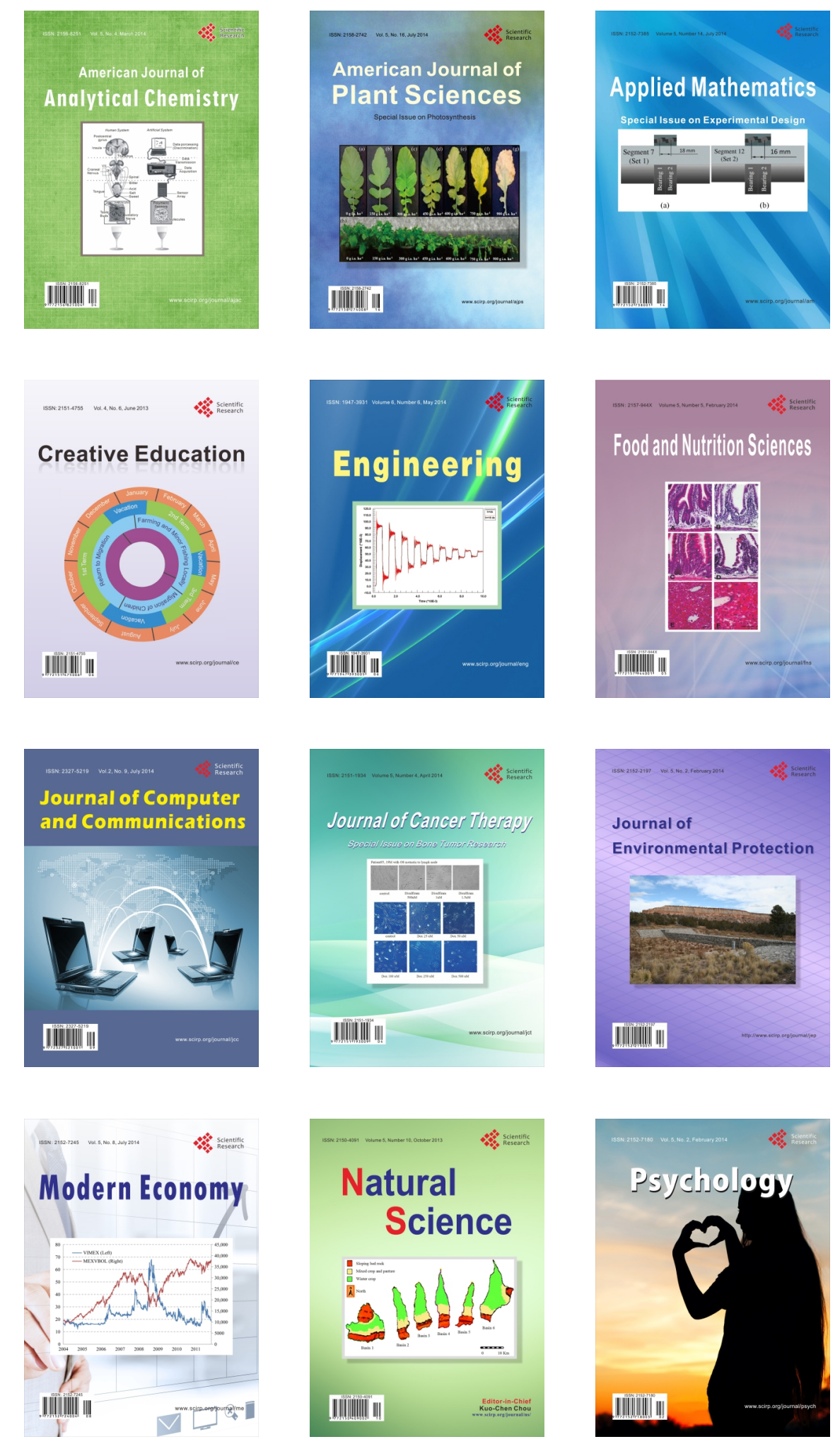